\title{
Supporting Student-Initiated Mobile Device Use in Online Learning
}

\author{
Karen L. Milheim \\ Christy Fraenza \\ Kimberly Palermo-Kielb \\ Walden University
}

\begin{abstract}
Understanding the experiences of students who self-initiate mobile device use for online courses or course-related activities provides institutions with valuable insights. In this study, we report how students enrolled in online courses in higher education voluntarily used mobile devices for their coursework and course-related activities, the challenges in using these devices, and how they managed those challenges. We surveyed 103 college students enrolled in one or more fully online courses regarding their habits in using mobile devices for online learning. Findings reveal most participants use mobile devices for convenience, portability, and overall ease of use. The way the devices are used for course-related activities varies, however, with reasons ranging from taking notes and reading course materials, to downloading those materials, communicating, socializing, and other purposes. Challenges when using these devices often relate to access issues and overall limitations of the technology. Yet, despite these limitations, some reported that, depending on the task, even though using a mobile device often took longer compared to a laptop or PC, the convenience of using it was a greater benefit. Participants were surveyed about their experiences prior to the COVID-19 pandemic, providing additional perspectives for possible future research focused on emergency circumstances to remote teaching or alternative forms of instruction. Additionally, this study provides a foundation of how and why students choose to use mobile devices for coursework and in what ways they may need support from their institutions related to their use.
\end{abstract}

Keywords: online learning; mobile learning; M-learning; online education; online courses; distance learning; distance education; instructional design; emergency remote teaching

Milheim, K., Fraenza, C., \& Palermo-Kielb, K., (2021). Supporting student-initiated mobile device use in online learning. Online Learning, 25(3), 267-288. doi:10.24059/olj.v25i3.2438 
The number of students voluntarily using devices other than PCs and laptops for their online coursework continues to rise (Magda \& Aslanian, 2018). With over $96 \%$ of Americans owning a cell phone of some kind (Pew Research Center, 2019), it is not surprising that mobile devices are becoming a popular, often preferred mode for engaging in online courses and courserelated activities (Clinefelter et al., 2019; Magda et al., 2020). Understanding the experiences of students who use mobile devices while taking an online course or courses, particularly those who self-initiate their use, provides institutions valuable insights. When the students self-initiate mobile device use for their online courses, there are a myriad of potential, negative impacts on their experiences. This is particularly notable when students engage in online courses not specifically designed for mobile learning on their devices. These issues include areas such as inability to consistently access (Perrin, 2019; Sadeque, 2020) or read (So, 2016; White, 2017) content, distractions when using devices (Cross et al., 2019; Pedro et al., 2018), and limitations when engaging in the course (Krull \& Duart, 2019), among others. For these and other reasons, as institutions continue to seek ways to support students regarding technology and online learning, mobile device users should not be ignored.

\section{Purposes of this Study}

The purpose of this qualitative study was to explore how students enrolled in online courses in higher education voluntarily use mobile devices for their coursework and courserelated activities. In addition, we were interested in understanding the challenges they encountered with respect to using these devices and how they overcame or attempted to overcome them. This study provides a foundation of how and why students choose to use a mobile device for coursework and in what ways they may need support from their institutions related to these areas.

As Martin et al. (2020) noted: "Online learning is no longer an innovation but has become the norm in [the] majority of the universities in the U.S. institutions" (p. 45). As such, institutions cannot assume that all students use only PCs or laptops for their online coursework. As institutions continue to seek ways to support students regarding technology and online learning, mobile device users should not be ignored, nor the challenges they may face due to factors such as device design and access limitations. The guiding Research Questions were:

1. Why do students who self-initiate mobile device use in their online course or courserelated activities choose to use the device?

2. How do students who self-initiate mobile device use in their online course or courserelated activities use the device?

3. What challenges do students who self-initiate mobile device use in their online course or course-related activities face, and how did they overcome those challenges?

\section{Mobile Device Defined}

\section{Review of Literature}

As new technologies and tools emerge, the definition and scope of the term "mobile device" continues to evolve. A review of earlier research references mobile devices as Personal Digital Assistants used for course activities such as reading and note-taking (Kukulska-Hulme, 2002). In 2004, Anderson and Blackwood described mobile devices as "mobile (or cellular) phones and also a range of information processing devices ranging from Personal Digital Assistants (PDAs) to more media-orientated gadgets that play video and MP3 music files" (p. 3). Along these same lines, Cain (2003) examined the issues and possibilities of the PDA, with a 
focus on research and access to library sites and databases. At the time, the author called on professionals "to be agile enough to either adapt themselves or be adapted with minimal effort" (p. 47). This ability for students to quickly adapt, and for technology to adapt with them, remains true today.

Presently, mobile devices can be described as a mobile personal computer; users can use them in many of the same ways they would a computer, albeit with the limitations of a smaller screen size (PC Magazine, 2020). The term "mobile device," as defined for this study, refers to a smartphone or tablet device. However, survey respondents were also asked to identify if they used another type of device they would identify as a mobile device. No other types of mobile devices were identified, either through the review of recent literature or responses from participants. This definition aligns with descriptions found in other recent studies as well (e.g., Ally \& Wark, 2018; Gallegos et al., 2019).

\section{Mobile Device Use in Online Learning}

According to a recent report, over $56 \%$ of online college students surveyed used a mobile device for at least some of their course-related activities (Clinefelter et al., 2019). Within the research, this voluntary use of mobile devices for learning has been referred to as "studentinitiated mobile learning" (Vasudeva et al., 2017). This is an important distinction from the umbrella term "mobile learning" (M-learning), which may include any or all elements of a course that are delivered via mobile technologies. These might include, for example, game-based learning, applications (Chuchu \& Ndoro, 2019; Troussas et al., 2020) or augmented reality (Radosavljevic et al., 2020) among many others. This distinction is vital to this study, as it is focused only on those who self-initiate mobile device use in their courses, not students in courses or activities specifically designed as M-learning.

Students highly value mobile devices as collaboration tools (Dabbagh et al., 2019; Heflin et al., 2017; Tang \& Bradshaw, 2016), allowing them to engage with coursework and communicate with instructors or peers at any given time or place (Ahmad, 2020; Anshari et al., 2017; Clinefelter et al., 2019; Cross et al., 2019; Fraga \& Flores, 2018). Text messaging or other applications support continuous contact and communication (McKinney \& Sen, 2016; So, 2016; Tang \& Bradshaw, 2016), letting group members efficiently work together on projects while in different locations (McKinney \& Sen, 2016; Vasudeva et al., 2017). This social aspect of mobile device use in course-related collaboration may have added value to the student experience and learning as well (Jiang \& Zhang, 2020), critical to cultivating relationships and providing opportunities for expansion of social networks (Dahya \& Dryden-Peterson, 2016; Sun et al., 2017).

More recently, during the COVID-19 pandemic (the "pandemic"), the use of mobile phones, in general, increased across all age groups, leading the use of laptops or desktop computers (Branscombe, 2020). As a response to the pandemic, many institutions shifted to emergency remote instruction in varying alternative models (e.g., online or hybrid formats) (Govindarajan \& Srivastava, 2020). This rapid shift prompted higher education institutions and researchers to re-evaluate and consider delivery of content, with attention to those students who used their mobile devices to access their courses (Naciri et al., 2020; Sandars et al., 2020). However, a global pandemic that impacted daily routines, finances, and technology access may impact learners in unexpected ways, far outside the typical student experience. As such, there is a lot to be gleaned from those who were self-initiating mobile device use for online courses before the pandemic; participants in this study offer these insights. 


\section{Challenges of Mobile Device Use in Online Learning Access Issues}

According to a recent report, $29 \%$ of adults with annual household incomes below $\$ 30,000$ do not own a smartphone; more than $44 \%$ do not have home broadband services or a traditional computer, with lower-income Americans not owning a tablet device (Anderson \& Kumar, 2019). This issue was at the forefront during the COVID-19 pandemic, with emergency transitions to online learning prompting some institutions to distribute mobile devices to help ensure student access to classes (Marinoni et al., 2020). For some students, not having affordable and easy access to a mobile device or reliable internet services may impede their desire or ability to use one for learning purposes or might hinder engagement with certain learning content due to limited data (Krull \& Duart, 2019). In the United States, there is still a significant digital divide, as many rural families may have little cell phone service and no internet, or slower internet speeds (Perrin, 2019). Similarly, as noted by Rideout and Katz (2016), many U.S. families experience interruptions in service due to missed payments or broken devices.

On a global scale, there are an estimated 3.6 billion individuals who do not have any internet access, mostly in developing countries (Sadeque, 2020); this is an important consideration for institutions with global student bodies (Al-Emran et al., 2016). As noted by Ahmad (2020), some countries face "significant infrastructural, institutional, socio-economic and financial resource constraints" (p. 26). For example, in a recent study focused on using mobile devices to improve access to online learning within multiple locations across Indonesia, connectivity was the primary limitation indicated by participants (Padmo et al., 2019), highlighting impediments created by poor infrastructure. Other environmental circumstances may also impact access or interrupt service, such as national crises, disasters, or frequent power outages (Chaka \& Govender, 2017; Holzweiss et al., 2020; Kaliisa et al., 2017). Beyond service issues, access to recent versions of devices may be an issue in many nations as well (Narayan \& Sharma, 2017).

When examining the challenges faced by students living in different countries, perspectives toward mobile device use in online learning varied. For example, students in Australia identified factors such as device features and social media distractions as primary challenges related to mobile device use in learning (Kaliisa et al., 2017). Conversely, students in Nigeria (Oyelere et al., 2016) and Egypt (Sobaih et al., 2016) identified poor infrastructure, resulting in limited or no internet access, as a primary challenge. Students living in certain areas where theft is a concern may also face increased possibilities of losing their mobile devices, and therefore their course access (Le Roux, 2016). These types of experiences indicate that country of residence is an important factor when considering the student experience, overall, with regards to mobile device use for learning (Kaliisa et al., 2017).

\section{User Experience}

Students who engage in self-initiated mobile device use for online courses must first have a positive perception of using a device for academic purposes (Fagan, 2019; Vasudeva, 2017). Limitations of a mobile device may influence how a student uses it. Students who self-initiate mobile device use for online courses or activities that were not designed for mobile learning (Mlearning) may be particularly at risk for a poor user experience. M-learning design considers the limitations of mobile devices in design technique, engagement, and usability (Eschenbrenner \& Nah, 2019; Kumar \& Goudnar, 2019; Suartama et al., 2019). Students should not expect these same considerations if they are engaging in an online course or course activities that were not specifically designed for mobile device users. 
The physical and technological characteristics of a mobile device can impact a student's ability to use it effectively and efficiently as a tool for academic work. The smaller screen and keyboard size may make it challenging to use the device for common tasks such as submitting assignments, reading materials, or writing content (Ahmad, 2020; Pimmer et al., 2016; So, 2016; Vrana, 2015). Small screen size can increase time spent reading (Al Ghamdi et al., 2016) or contribute to students only feeling comfortable using mobile devices for low-stakes tasks (Hu et al., 2016). Readability issues related to screen size may make it difficult to see more robust displays of content and images (So, 2016; White, 2017), which may influence learning outcomes, overall. Similarly, a learner's level of understanding of the functionality of their device, particularly for learning, may be a challenge (El-Sofany \& El-Haggar, 2020; FiguerasMaz et al., 2017).

\section{Distractions}

Outside of the inherent technical issues faced by students using a mobile device, a personal mobile device also opens the door to more distractions - with social media, web browsing (Cross et al., 2019), and endless apps and games only a quick tap away. This easy access, combined with push notifications from many apps, results in a constant competition for students' attention (Pedro et al., 2018). Multitasking with social media or answering text messages via a mobile device while engaging in a learning activity can negatively impact academic performance (Junco, 2012). In the traditional classroom, an instructor can help to mitigate the distractions by having students put away devices, but online students must regulate their own behavior (Cross et al., 2019). Some online students may struggle with easy access to other online platforms and be distracted from academic work, which may limit any potential positive impact of mobile device use.

\section{Design}

\section{Methods}

A basic qualitative research design was used to uncover student experiences related to self-initiated mobile device use in online courses or course-related activities (Creswell \& Creswell, 2017; Merriam, 2002; Merriam \& Tisdell, 2015). Before collecting any data, the researchers obtained Institutional Review Board approval from their institution. An anonymous, online survey was developed and posted on the website SurveyCircle, a platform where researchers around the world can participate in research or recruit participants. The survey was also posted within the online participant pool at the researchers' institution, a global online forprofit institution based in the U.S. Also, the researchers posted the survey link on LinkedIn and other social media sites to maximize recruitment strategy (Benfield \& Szlemko, 2006), including the social media page for SurveyCircle. This sharable survey link allowed for snowball sampling, as participants were invited to share it with their acquaintances to support increased sample size (Sharma, 2017; Taherdoost, 2016).

\section{Instrument}

The researchers developed an anonymous, online survey that began with two screening questions designed to verify that participants met the inclusion criteria. To qualify, participants needed to (a) be enrolled in a fully online course at the time of participation or have taken such a course within the last 6 months and (b) voluntarily used a mobile device for coursework or course-related activities. The screening questions were followed by five demographic questions designed to provide a descriptive summary of the participants. The remaining section of the 
survey consisted of five short answer questions and three multiple-choice questions designed to provide data to answer the research questions. These questions explored participant experiences using a mobile device for online coursework or course-related activities. These questions centered around topics relevant to what devices are used, for what reasons they are used, what challenges are experienced, and what strategies are used to overcome challenges. The full survey instrument is provided in the Appendix.

\section{Participants}

Out of 144 responses, 103 participants met the two screening criteria and completed the full survey. Of those who took the full survey, two questions asked participants about mobile device use to better understand general user habits, including: (a) frequency of use compared to a laptop or computer and (b) the average number of times per week the device was used. Sixty-two participants (66\%) reported they use a mobile device less often compared to a laptop or computer, 28\% (26 out of 94) more often, and 6\% (6 out of 94) use only a mobile device for their online coursework (9 participants did not respond). Forty-one participants (43\%) reported they use their mobile device 3-5 times per week, on average. Twenty-five participants (26\%) use their mobile device 0-2 times per week, and $19(20 \%)$ use their device 6-10 times per week. Over $10 \%$ of participants use their mobile device more than 10 times per week for course or courserelated activities ( 8 participants did not respond). An overview of the frequency of mobile device use is provided in Table 1. Additional participant demographics are reported in Table 2.

\section{Table 1}

Frequency of Mobile Device Use

\begin{tabular}{|c|c|c|c|}
\hline & & Frequency & Percentage \\
\hline \multirow{3}{*}{$\begin{array}{l}\text { Mobile device use compared } \\
\text { to a laptop or computer }\end{array}$} & Use a mobile device less often & 62 & $66 \%$ \\
\hline & Use a mobile device more often & 26 & $28 \%$ \\
\hline & Only use a mobile device & 6 & $6 \%$ \\
\hline \multirow{4}{*}{ Weekly mobile device use } & 3 to 5 times per week & 41 & $43 \%$ \\
\hline & 0 to 2 times per week & 25 & $26 \%$ \\
\hline & 6 to 10 times per week & 19 & $20 \%$ \\
\hline & More than 10 times per week & 10 & $11 \%$ \\
\hline
\end{tabular}

Table 2

Participant Demographics

\begin{tabular}{|llccc}
\hline \multicolumn{1}{|c}{} & & Frequency & Percentage \\
\hline \multirow{4}{*}{ Age } & $18-29$ & 58 & $56 \%$ \\
& $30-49$ & 36 & $35 \%$ \\
& $50-64$ & 9 & $9 \%$ \\
\hline \multirow{4}{*}{ Gender } & Female & Male & 71 & $69 \%$ \\
& Prefer Not to Respond & 31 & $30 \%$ \\
& White & 1 & $1 \%$ \\
\hline \multirow{5}{*}{ Ethnic/Racial } & Asian/Pacific Islander & 72 & $70 \%$ \\
Background & African American/Black & 12 & $12 \%$ \\
& Prefer Not to Answer & 11 & $11 \%$ \\
& Other/Not Listed & 3 & $3 \%$ \\
& Hispanic/Latino & 3 & $3 \%$ \\
\hline
\end{tabular}




\begin{tabular}{|l|lrc|}
\hline \multirow{5}{*}{ Level of Program } & Bachelor's & 43 & $42 \%$ \\
& Master's & 26 & $25 \%$ \\
& Doctoral & 22 & $21 \%$ \\
& Other & 8 & $8 \%$ \\
& Post-graduate certificate & 4 & $4 \%$ \\
\hline \multirow{5}{*}{ Field of Study } & Psychology \& Counseling & 41 & $43 \%$ \\
& Business \& Management & 20 & $21 \%$ \\
& Education & 11 & $12 \%$ \\
& Other & 9 & $9 \%$ \\
& Public Health \& Health Sciences & 6 & $6 \%$ \\
& Social Work \& Human Services & 3 & $3 \%$ \\
& Criminal Justice & 2 & $2 \%$ \\
& Public Policy \& Administration & 2 & $2 \%$ \\
& Communication & 1 & $1.0 \%$ \\
\hline
\end{tabular}

Data analysis of each short answer question was guided by Braun and Clark's (2006) six-phase guide for qualitative analysis. Data was hand-coded through an inductive process. The process started with reading and re-reading the participant responses, listing each of the responses per question, and color-coding the responses that were alike. Next, the color-coded data was counted for frequencies and categorized to look for patterns and to derive themes. For qualitative credibility purposes, the raw color-coded data was shared with the other two authors for a quality check before developing main themes.

\section{Self-Initiated Mobile Device Use}

\section{Findings}

\section{Theme 1: Choosing a Mobile Device for Convenience and Portability}

Results of the survey reveal that students who self-initiate mobile device use for online courses or course-related activities often choose to do so because of convenience and portability. Several participants described that their mobile device is especially useful when they commute to work or do not have a laptop available. Furthermore, some indicated that because their mobile device is readily available, they can participate in their course discussions and interactive lectures and access email no matter where they are. One participant stated, "I use my mobile device for convenience when I am not at home so that I can still participate in the discussion and email." One participant noted that their mobile device is "always on hand," while another shared, "I always have it so if I realize I have to turn something in right away and I don't have my laptop I can just use my phone."

Participants noted that they like the comfort of their mobile devices, as they are less bulky or heavy compared to a laptop, textbook, and notebook. Along these lines, participants described that with their mobile device, they do not have to be at a standstill, as they can do their coursework or research work on their mobile device in their spare time and can multitask. One participant shared, "it's easier to not have to be tied down to an actual computer, the ability to move about the house while working makes it easier to get the work needed done."

\section{Theme 2: Using a Mobile Device for its Practicality and Efficiency}

While the "on the go" nature of the mobile device is an important consideration in why participants use mobile devices for their online courses, it was not the only reason they choose to use a mobile device. Multiple students highlighted the practical application of using a mobile 
device. The functionality of a mobile device prompts one participant to listen to readings, sharing that they access the "text to speech function to listen to readings that I downloaded." One participant noted they use their mobile device for "Googling things I don't know as I encounter them," while another participant shared, "rather than be confined to the computer, I download the pdf [sic] and read on Kindle or iPad." This efficiency was described by several as the primary reason they choose to use their mobile device, noting their preference for using a mobile device for quick tasks, such as checking in on their courses and jotting down notes. Furthermore, participants responded that their mobile devices simplify their planning and organization, allowing them to keep up with the pace of the course. One participant stated they "work many hours, and the smartphone simplifies my planning and organization," while another participant noted are "able to quickly respond when traveling."

\section{Primary Uses of Mobile Devices}

\section{Theme 1: Engaging with the Course Content}

How participants use mobile devices varies. Many described they use their mobile device primarily for accessing the Learning Management System (LMS) and course-related materials. The reasons for accessing the LMS varied, including activities such as reading announcements, checking grades, submitting assignments, and taking online quizzes. Also, nearly half of participants indicated they engage with some or all course content via their mobile device to read course materials (e.g., articles and e-books), watch or listen to lectures, and access other content related to their courses. Several reported using their mobile devices for researching information on different topics, searching for course resources, and reviewing notes while not at their computer.

\section{Theme 2: Communicating with the Learning Community}

In addition to accessing the LMS or engaging with the course content, nearly half of participants use the mobile device as a communication tool, mainly to email instructors or connect with classmates. The modes for doing so varied, however, including chatting, messaging, and texting classmates to clarify assignments, scheduling and attending meetings via Slack, Zoom, Skype, and Google, and participating in classroom discussion forums and social media groups. Direct communication with faculty was limited to email and phone calls, but participants connect with peers in several ways using their mobile devices. For example, participants noted they used a mobile device for a "scheduled phone meeting with Professor." However, other participants shared they use their mobile device for "Facebook messaging group members," to "text classmates to clarify assignments, use "group chat with classmates, and use "WhatsApp for group work."

\section{Student Challenges with Mobile Device Use \\ Theme 1: Experiencing Compatibility Issues}

The types of challenges participants described relevant to self-initiated mobile device use varied, with nearly half noting device compatibility with the course or course materials as a primary barrier. More specifically, these included issues relevant to accessing the LMS and other applications, typing and formatting papers, and accessing attachments and media resources. One participant shared, "as I have advanced in my studies the need to write and edit has become a cornerstone of my work and the device I use does not support this activity." Another participant shared, "not all media resources provided by lecturers is compatible with mobile devices," while another participant noted that "my biggest issue with using my mobile device is that I do not have Grammarly or Word to spell check." 
Related, participants also described software or device limitations as a challenge in using them for their online coursework. These are described as pages not loading correctly, applications working inconsistently, issues with the touchscreen, and trouble accessing some functions and links. One participant shared that:

when trying to access some of the online pages which are clearly set up more for PC use, it can be frustrating to try and click on the relevant part of the screen as it doesn't recognize me touching the screen when using my smart phone, or the screen touch is too responsive so it will open and close a screen without me actually wanting to do so. Along these lines, another participant shared that "sometimes if my phone doesn't have the most current updates, it affects the Blackboard app and I can't use certain functions."

\section{Theme 2: Encountering Challenges Due to Device Design}

Device design presents challenges as well, with readability issues, and slow connectivity identified by over one-quarter of participants as a challenge. Small screen size, visibility restrictions, small font size, and screen formatting problems creates a poor student experience. One participant shared, "the biggest challenge is not being able to enlarge the font and maintain the ability to view the whole page like you can when reading an e-book, for example," while another participant shared that the "limited view on screen" was a challenge. Another participant shared that "getting articles to display properly and making them large enough to read comfortably" was a challenge. Compounding these issues were slow connections, signal interruptions, privacy concerns, and issues loading websites, documents and files were frequently described as barriers to using a mobile device. One participant shared, "use to extended road travel - there are points where signals are limited - hence interactions with classmates may be interrupted," while another shared that they experienced "slow load time."

\section{Resolving Mobile Device Challenges \\ Theme 1: Attempting to Self-Resolve}

Many participants described attempts to self-resolve challenges in using their mobile devices, with nearly half reporting that they switched to a computer or hardcopy (i.e., moving to paper) as a solution. One participant shared, "I was unable to resolve my issues, so I used a regular computer to complete written assignments," while another shared "I was not able to resolve the problem and completed the task later on my laptop." If the problem was an issue with formatting or readability, several noted that they enlarge the text or look for webpages compatible with mobile devices. One participant shared that 'devices have 'desktop view,' but this is often only marginally better," while another shared, "I was able to figure out how to enlarge the text. The only downside to enlarging the test is that the page numbers become off." Connection challenges were also often reported as being self-resolved; many participants responded they would reset the device, update an app, or move to a location with better Wi-Fi.

Not all reported challenges with mobile device use were resolved. Several reported that "patience" and "caution" were important in addressing the challenge, with one participant noting, "I have to carefully click what I need and therefore be a bit more slower than I would usually be," while another shared "waiting patiently" is how they address the challenge. Those instances in which challenges went unresolved, led to frustration. One participant shared, "I was not able to resolve it, I had to deal with frustration." Another shared, "I just used it, it was never resolved."

\section{Theme 2: Seeking Outside Support}

Nearly one-quarter of participants shared that others, such as technical support or classmates were a source of help. One participant noted, "I honestly will ask my students for 
help. I am a high school teacher," while another participated shared that "calling tech support may provide answers." During communication interruptions, one participant shared, "I make my classmates aware. They usually take a break at point of lost contact and give me the opportunity to reconnect."

\section{Suggested Resolutions}

\section{Theme 1: Considering Content Design}

Over half of participants suggested more mobile-friendly design of content as a potential resolution to their issues. Many indicated that applications used for online courses education should be configured for mobile devices. One participant shared, "I feel that the apps for my coursework could be better formatted for mobile devices," while another wrote they could resolve challenges "if the website pages were designed with phone/tablets in mind rather than being really just set up for PC use." Another participant shared, "I think they could make a spell check, and grammar check like Grammarly for mobile device keyboards."

\section{Theme 2: Preparing for Technology Challenges}

Over a quarter of participants indicated they should be better prepared for the possibility of issues with technology. Many described their desire to be more adept with how to operate their mobile devices to understand ways to resolve problems. One participant noted they could have "more patience or learning about potential solutions," while another shared that they could "learn how to operate additional functions on the phone." Several indicated that administrative teams should be available to resolve the issue, rather than relying on the student.

\section{Theme 3: Choosing an Alternative Device}

Some acknowledged that sometimes the mobile device is not the best choice for academic work at all, due to device size or limitations. For example, one participant shared, "I probably should have gotten a note phone or a tablet so I would have a bigger screen," while another shared the challenges could have been resolved by "using a laptop instead." Participants noted they should have chosen or used a different, larger device.

\section{Importance of Flexibility}

\section{Discussion}

How and when participants use their mobile device highlights the desire of students to be able to maintain access to their academic work and materials while traveling, commuting, and working. Participants valued being able to connect even when on-the-go, which aligns with previous research illustrating the desire of online learners to have a flexible learning experience (Cross et al., 2019). While most participants reported they use a computer or laptop more frequently than a mobile device, students still frequently rely on a mobile device multiple times per week to engage in quick tasks related to their coursework. As noted in previous studies, participants often switch between devices to support their efficiency (Krull \& Duart, 2019). Despite challenges when using their mobile devices for academic purposes, many continued to rely on the mobile device, perhaps because of the portability and convenience of being able to quickly communicate with others, find information, or engage with course-related content. This pattern suggests that even when challenges exist, students may find the convenience and efficiency possibilities of connecting on-the-go as a top priority.

Research shows that student preferences for using a mobile device for learning is increasing, with students interested in online programs being more likely to use a mobile device (Magda et al., 2020). Given the increasing number of students who are voluntarily using mobile devices for their learning, institutions should not ignore this growing group. It is worth noting 
that participants in this study were split among the bachelor's (42\%), master's (25\%), and doctoral $(21 \%)$ levels. Yet, findings did not indicate any particular use patterns when comparing the preferences, habits, or challenges faced by these groups. Similarly, participants from different age groups showed no distinct differences, suggesting that adult learners and those from the younger generations experience similar benefits and challenges when choosing to use a mobile device for online courses, and choose to use a mobile device at similar rates and in similar ways. Interestingly, these generational similarities contradict other findings showing that learners 45 years and older are less likely to use mobile devices for learning activities (Clinefelter et al., 2019). While there is not enough data to draw any defined conclusions, this does indicate the need to consider further research in this area.

\section{Mobile-Friendly Course Design}

It is important to note that research exploring student habits regarding why they use mobile devices for learning often uses the term M-learning as a generic term. This may create an imprecise understanding of the research and student experience. When limitations of mobile learning are discussed, it is often unclear if the course setting was specifically designed for this modality (Bateman \& Palilingan, 2017), making it difficult to ascertain the true experience of learners and reasons for any challenges they may have faced.

What is clear from this study and others (Clinefelter et al., 2019; Magda et al., 2020) is that students continue to use mobile devices for their online courses or course-related activities, even if those courses are not designed for M-learning. Institutions must remain mindful of this group of students, as participants noted the challenges they experienced when trying to access courses and course-related content from their mobile device. While many institutions are focused on adapting existing courses to align with M-learning principles, students in this study indicated the need for broader mobile-friendly considerations beyond the classroom itself. For example, websites, documents, and additional resources must also be designed in a mobile-friendly way to increase the accessibility and user experience of self-initiated mobile device learners. Considering the accessibility of these items on a mobile device is essential, given the desire of students to complete readings on a mobile device, and the possibility of an increased reliance on such devices for class communications and coursework (Magda et al., 2020). This comparison between M-learning experiences and challenges versus the experiences of those students who self-initiate mobile device use may glean insights into the student experience from these unique groups of learners. This distinction also highlights the need for a more precise approach to mobile learning research by focusing on characteristics of the learning environment and how those features can support student goals (Grant, 2019).

The emergency transition to remote instruction during the pandemic revealed the differences between emergency remote teaching and online learning (Hodges et al., 2020). While some research refers to this sudden use of mobile devices for learning in higher education as mobile learning (Biswas et al., 2020), the distinction from self-directed mobile device use is critical. Online learning is designed as online being the primary mode of instruction, prepared over time, with proper training of staff and other considerations (Shisley, 2020). These considerations should also extend to mobile learners through mobile-friendly course design. Knowing how students are accessing a course, and deliberately designing for PC, laptop, and mobile learners, will support a positive student experience. While some participants suggested they should not have used a mobile device at all, this is not necessarily ideal for those who do not 
have access to another tool or face other limitations. Nor does it consider those who prefer their mobile device for its convenience. Institutions must consider a balance between those who (a) prefer mobile devices to computers, (b) use them because they do not have access to another device, or (c) use the device because it offers features that are not as easy to use on a computer (i.e., listening to a podcast of a lecture).

\section{Technical Support}

From an institution standpoint, mobile device use creates a challenge for the design and implementation of resources for a variety of reasons. Because students do not all use the same types of devices, the institution cannot limit support to a single type or style of device. Students will seek out support that is device specific (Gikas \& Grant, 2013) and may experience frustration when they are unable to resolve challenges with their device (Regalado \& Smale, 2019). Given the wide variety of device models and platforms, it seems likely that students using mobile devices will face challenges in getting institution-level technological support, and that some users will face barriers in the access and use of some content. In this study, multiple participants noted the need for them to become more familiar with the features of their mobile devices to overcome challenges.

The need to better understand the functionality of mobile devices may extend beyond specific technical issues, however, and could determine if mobile devices support or hinder student learning. For example, Hartley and Bendixen (2019) noted the need for students to understand how installed applications could help them by sending reminders or, conversely, distract them by sending constant notifications. As technology changes, institutions cannot feasibly create support materials for every single mobile device or application. They could, however, curate resources from major mobile device companies so students can quickly locate external help and support. These resources might inform students, for example, about general mobile device features, such as how popular apps use notifications. Even though mobile devices are widely used by students (Magda et al., 2020), what is clear is that institutions should not assume that all learners understand how to effectively use such tools or overcome challenges when engaging in course-related activities.

For those institutions who provide mobile devices to ensure access to online courses, as some did during the pandemic (Marinoni et al., 2020), those institutions should consider offering technical support for those specific devices. As findings of this study revealed, several participants' challenges went unresolved. In these situations, it is unclear if this negatively affected or hindered the students' experiences or progress. However, other researchers have noted that some students may become frustrated when technology does not work properly (Olt \& Teman, 2018), which may influence student success, overall (Kakada et al., 2019). Additionally, consistent with other studies (Gikas \& Grant, 2013), many participants in the current study noted they switched to a different device when faced with mobile device challenges. Being able to switch to another device may not be an option for all learners, however, as some students may not have access to other devices, or their devices may not be suitable for given tasks (Brown \& Haupt, 2018). This behavior is particularly interesting in the context of the pandemic, when some institutions provided devices to learners who may not have secondary devices at home. These student patterns and challenges are important considerations if institutions are focused on creating mobile-friendly courses or other resources. Even with such focus and careful design, there are some students who may still face barriers when it comes to using a mobile device for such purposes. 


\section{Limitations and Future Research}

There were several limitations to this study. While there are benefits to using snowball sampling to recruit participants, there are also limitations. As Geddes et al. (2018) described, snowball sampling can often falter, prompting the researchers to seek alternative ways to recruit participants. In this study, the method created a loss of control over the sample. To address this concern, questions related to institutional profile and available supports would have added additional context regarding participant responses. Along these lines, this study did not take into consideration the cultural backgrounds of participants. Yet, due to the variety of recruitment strategies, participants could come from diverse locations, programs, and backgrounds from around the world. While this was not the focus of the research, it should not be ignored, as there are global implications related to device use, infrastructure, and other areas that could factor into the findings.

In addition, it is important to note that data collection for this study was completed before the COVID-19 pandemic that impacted many students and institutions on a global scale. As many more institutions moved to online delivery in response, users experienced issues related to interrupted internet access and overwhelmed servers. These perspectives and experiences were not captured in data collection. Therefore, the results of this study are reflective of a more typical student experience not impacted by these circumstances. This creates, however, an opportunity for future research. Further exploration of the experiences of this same population of students would provide further insights into the student experience after an unexpected transition to online learning.

The survey instrument did not ask participants specifically about access to a device or multiple devices. Yet, as several participants in this study indicated, they switched between several devices when they face challenges with their mobile device. However, this is not an option every student has. As many students are only using a mobile device for their coursework, further research is needed to understand challenges faced specifically by those students who only have access to a mobile device for online coursework. Future research should consider gathering this information to gain a clearer understanding of this area.

This study confirms the themes revealed in the review of current literature relevant to student-initiated mobile device use in online learning. It also illuminates the gap in research focused specifically on this group of learners. As the term M-learning becomes more common, there must be an explicit distinction between the terms mobile-learning and mobile-friendly design. With this distinction, understanding the experiences of students who self-initiate mobile device uses in online learning compared to courses or activities designed specifically for Mlearning will become more apparent. 


\section{References}

Ahmad, T. (2020). Student perceptions on using cell phones as learning tools. PSU Research Review, 4(1), 25-43. https://doi.org/10.1108/PRR-03-2018-0007

Al-Emran, M., Elsherif, H.A., \& Shaalan, K. (2016). Investigating attitudes towards the use of mobile learning in higher education. Computers in Human Behavior, 56, 93-102. https://doi.org/10.1016/j.chb.2015.11.033

Al Ghamdi, E., Yunus, F., Da’Ar, O., El-Metwally, A., Khalifa, M., Aldossari, B., \& Househ, M. (2016). The effect of screen size on mobile phone user comprehension of health information and application structure: An experimental approach. Journal of Medical Systems, 40(1), 11. https://doi.org/ 10.1007/s10916-015-0381-5

Ally, M., \& Wark, N. (2018). Online student use of mobile devices for learning. In D. Parsons, R. Power, A. Palalas, H. Hambrock, \& K. MacCallum (Eds.), Proceedings of the World Conference on Mobile and Contextual Learning (pp. 8-13). The Learning and Technology Library. https://www.learntechlib.org/p/184917/

Anderson, P., \& Blackwood, A. (2004). Mobile and PDA technologies and their future use in education. JISC Technology and Standards Watch, 4(3), 3-33.

Anderson, M. \& Kumar, M. (2019, May 7). Digital divide persists as lower income Americans make gains in tech adoption. Pew Research Center. https://www.pewresearch.org/facttank/2019/05/07/digital-divide-persists-even-as-lower-income-americans-make-gains-in-techadoption/

Anshari, M., Almunawar, M.N., Shahrill, M., Wicaksono, D.K., \& Huda, M. (2017). Smartphones usage in the classrooms: Learning aid or interference. Education and Information Technologies, 22(6), 3063-3097. https://doi.org/10.1007/s10639-017-9572-7

Batmetan, J. R., \& Palilingan, V. R. (2018). Higher education students' behavior to adopt mobile learning. In A.G. Abdullah, E.A.B.D. Nandiyanto, I. Widiaty, \& V. Palilingan (Eds.), Proceedings of the 2nd International Conference on Innovation in Engineering and Vocational Education. IOP Science. https://doi.org/10.1088/1757-899X/306/1/012067

Benfield, J.A., \& Szlemko, W.J. (2006). Internet-based data collection: Promises and realities. Journal of Research Practice, 2(2). http://jrp.icaap.org/index.php/jrp/article/view/30/51

Biswas, B., Roy, S., \& Roy, F. (2020). Students perception of mobile learning during the COVID-19 pandemic. Aquademia, 4(2), ep20023. https://doi.org/10.29333/aquademia/8443

Branscombe, M. (2020). The network impact of the global COVID-19 pandemic. The news stack. https://thenewstack.io/the-network-impact-of-the-global-covid-19-pandemic/

Braun, V., \& Clarke, V. (2006). Using thematic analysis in psychology. Qualitative Research in Psychology, 3, 77-101. https://doi.org/10.1191/1478088706qp063oa 
Brown, C., \& Haupt, G. (2018). Using personal mobile devices to increase flexibility and equity in learning in resource-constrained contexts. Journal of Open, Flexible, and Distance Learning, 22(2), 18-31.

Cain, M. (2003). PDA: Paradigm-disrupting appliance? Journal of Academic Librarianship, 29(1), 44-88. https://doi.org/10.1016/S0099-1333(02)00398-1

Chaka, J.G., \& Govender, I. (2017). Students' perceptions and readiness towards mobile learning in colleges of education: A Nigerian perspective. South African Journal of Education, 37(1). https://doi.org/10.15700/saje.v37n1a1282

Chuchu, T. \& Ndoro, T. (2019). An examination of the determinants of the adoption of mobile applications as learning tools for higher education students. International Association of Online Engineering. https://www.learntechlib.org/p/208275/

Clinefelter, D. L., Aslanian, C. B., \& Magda, A. J. (2019). Online college students 2019: Comprehensive data on demands and preferences. Wiley Education. https://edservices.wiley.com/wp-content/uploads/2019/07/OCS-2019-FINAL-WEB-Report.pdf

Creswell, J. W., \& Creswell, J. D. (2017). Research design: Qualitative, quantitative, and mixed methods approaches. Sage Publications.

Cross, S., Sharples, M., Healing, G., \& Ellis, J. (2019). Distance students' use of handheld technologies: Mobile learning activity, changing study habits, and the 'place' of anywhere learning. International Review of Research in Open and Distributed Learning, 20(2), 223-241. https://doi.org/10.19173/irrodl.v20i2.4040

Dabbagh, N., Fake, H., \& Zhang, Z. (2019). Student perspectives of technology use for learning in higher education. Revista Iberoamericana de Educación a Distancia, 22(1), 127-152. https://doi.org/10.5944/ried.22.1.22102

Dahya, N., \& Dryden-Peterson, S. (2017). Tracing pathways to higher education for refugees: The role of virtual support networks and mobile phones for women in refugee camps. Comparative Education, 53(2), 284-301. https://doi.org/10.1080/03050068.2016.1259877

El-Sofany, H., \& El-Haggar, N. (2020). The effectiveness of using mobile learning techniques to improve learning outcomes in higher education. International Journal of Interactive Mobile Technologies, 14(8), 4-18. https://www.online-journals.org/index.php/i-jim/article/view/13125

Eschenbrenner, B., \& Nah, F. F. H. (2019). Learning through mobile devices: Leveraging affordances as facilitators of engagement. International Journal of Mobile Learning and Organisation, 13(2), 152-170. https://doi.org/10.1504/IJMLO.2019.098193

Fagan, M.H. (2019). Factors influencing student acceptance of mobile learning in higher education. Computers in the Schools, 36(2), 105-121. https://doi.org/10.1080/07380569.2019.1603051 
Figueras-Maz, M., Masanet, M. J., \& Ferrés, J. (2017). Mobile devices in higher education: A pending issue in multidimensional media literacy. Catalan Journal of Communication \& Cultural Studies, 9(1), 135-144. https://doi.org/10.1386/CJCS.9.1.135_1

Fraga, L. M., \& Flores, B. B. (2018). Mobile learning in higher education. In J. Keengwe (Ed.), Handbook of research on mobile technology, constructivism, and meaningful learning (pp. 123146). IGI Global. https://doi.org/ 10.4018/978-1-5225-3949-0

Gallegos, C., Gehrke, P., \& Nakashima, H. (2019). Can mobile devices be used as an active learning strategy? Student perceptions of mobile device use in a nursing course. Nurse Educator, 44(5), 270-274. https://doi.org/10.1097/NNE.0000000000000613

Gikas, J., \& Grant, M.M. (2013). Mobile computing devices in higher education: Student perspectives on learning with cellphones, smartphones \& social media. The Internet and Higher Education, 19, 249-261. https://doi.org/10.1016/j.iheduc.2013.06.002

Geddes, A., Parker, C., \& Scott, S. (2018). When the snowball fails to roll and the use of 'horizontal' networking in qualitative social research. International Journal of Social Research Methodology, 21(3), 347-358. https://doi.org/10.1080/13645579.2017.1406219

Govindarajan, V., \& Srivastava, A. (2020, June 2). A post-pandemic strategy for U.S. higher ed. Harvard Business Review. https://hbr.org/2020/06/a-post-pandemic-strategy-for-u-s-higher-ed

Grant, M. M. (2019). Difficulties in defining mobile learning: Analysis, design characteristics, and implications. Educational Technology, Research and Development, 67(2), 361-388. https://doi.org/10.1007/s11423-018-09641-4

Hartley, K., \& Bendixen, L.D. (2019). Smartphones and self-regulated learning: Opportunities and challenges. In I.A. Sanchez, P. Isaias, P. Ravesteijn, \& G. Ongena (Eds.), Proceedings of the 15th International Conference on Mobile Learning (pp. 148-152). International Association for Development of the Information Society.

Heflin, H., Shewmaker, J., \& Nguyen, J. (2017). Impact of mobile technology on student attitudes, engagement, and learning. Computers \& Education, 107, 91-99.

https://doi.org/10.1016/j.compedu.2017.01.006

Hodges, C., Moore, S., Lockee, B., Trust, T., \& Bond, A. (2020, March 27). The difference between emergency remote teaching and online learning. EDUCAUSE Review. https://er.educause.edu/articles/2020/3/the-difference-between-emergency-remote-teaching-andonline-learning

Holzweiss, P. C., Walker, D. W., Chisum, R., \& Sosebee, T. (2020). Crisis planning for online students: Lessons learned from a major disruption. Online Learning, 24(2), 22-37. https://doi.org/10.24059/olj.v24i2.2135 
Hu, X., Lei, L. C. U., Li, J., Iseli-Chan, N., Siu, F. L., \& Chu, S. K. W. (2016). Access Moodle using mobile phones: Student usage and perceptions. In D. Churchill, J. Lu, T. Chiu, \& B. Fox (Eds.), Mobile learning design (pp. 155-171). Springer.

Jiang, D., \& Zhang, L. J. (2020). Collaborating with 'familiar' strangers in mobile-assisted environments: The effect of socializing activities on learning EFL writing. Computers \& Education, 150. https://doi.org/10.1016/j.compedu.2020.103841

Junco, R. (2012). In-class multitasking and academic performance. Computers in Human Behavior, 28(6), 2236-2243. https://doi.org/10.1016/j.chb.2012.06.031https://digitalliteracy.cornell.edu/

Kakada, P., Deshpande, Y., \& Bisen, S. (2019). Technology support, social support, academic support, service support, and student satisfaction. Journal of Information Technology Education, 18, 549-570. https://doi.org/10.28945/4461

Kaliisa, R., Palmer, E., \& Miller, J. (2017). Mobile learning in higher education: A comparative analysis of developed and developing country contexts. British Journal of Educational Technology, 50(2), 546-561. https://doi.org/10.1111/bjet.12583

Kukulska-Hulme, A. (2002, June 20-21). Cognitive, ergonomic, and affective aspects of PDA use for learning. In European Workshop on Mobile and Contextual Learning (pp. 20-21). mLearn. http://oro.open.ac.uk/49020/2/kukulska-hulme\%20-\%20mlearn2002.pdf

Kumar, B. A., \& Goundar, M. S. (2019). Usability heuristics for mobile learning applications. Education and Information Technologies, 24(2), 1819-1833. https://doi.org/10.1007/s10639019-09860-z

Krull, G., \& Duart, J. M. (2019). Supporting seamless students: Exploring patterns of multiple device use in an open and distancing learning context. Research in Learning Technology, 27. http://dx.doi.org/10.25304/rlt.v27.2215

Le Roux, S. (2016). Mobile learning in practical-based subjects: A developing country perspective. In L. E. Dyson, W. Ng, \& J. Fergusson (Eds.), Proceedings of the World Conference on Mobile and Contextual Learning (pp. 149-160). mLearn.

https://www.academia.edu/download/51328054/Proceedings_MLearn2016Final.pdf\#page=149

Magda, A. J., Capranos, D., \& Aslanian, C. B., (2020). Online college students 2020:

Comprehensive data on demands and preferences. Wiley Education Services.

https://edservices.wiley.com/ocs2020/

Magda, A. J., \& Aslanian, C. B. (2018). Online college students 2018: Comprehensive data on demands and preferences. The Learning House. https://49hk843qupwu3gfmw73ngy1kwpengine.netdna-ssl.com/wp-content/uploads/2018/06/OCS-2018-Report-FINAL.pdf 
Marinoni, G., Land, H. V., \& Jensen, T. (2020). The impact of COVID-19 on higher education around the world: IAU global survey report. International Association of Universities. https://www.iau-aiu.net/IMG/pdf/iau_covid19_and_he_survey_report_final_may_2020.pdf

Martin, F., Stamper, B., \& Flowers, C. (2020). Examining student perception of their readiness for online learning: Importance and confidence. Online Learning, 24(2), 38-58.

https://doi.org/10.24059/olj.v24i2.2053

McKinney, P., \& Sen, B. (2016). The use of technology in group-work: A situational analysis of students' reflective writing. Education for Information, 32, 375-396.

https://doi.org/10.3233/EFI-160983

Merriam, S. B. (2002). Qualitative research in practice: Examples for discussion and analysis. Jossey-Bass.

Merriam, S. B., \& Tisdell, E. J. (2015). Qualitative research: A guide to design and implementation. Wiley.

Naciri, A., Baba, M. A., Achbani, A., \& Kharbach, A. (2020). Mobile learning in Higher education: Unavoidable alternative during COVID-19. Aquademia, 4(1), ep20016. https://doi.org/10.29333/aquademia/8227

Narayan, J., \& Sharma, S. (2017). Mobile learning in higher education: A South Pacific perspective. International Journal of Instructional Technology and Distance Learning, 14(4), 39-55. http://repository.usp.ac.fj/id/eprint/10347

Olt, P.A., \& Teman, E.D. (2018). A duoethnographic exploration of persistent technological failures in synchronous online education. Forum: Qualitative Social Research, 19(3), https://doi.org/10.17169/fqs-19.3.3039

Oyelere, S. S., Suhonen, J., Shonola, S. A., \& Joy, M. S. (2016). Discovering students mobile learning experiences in higher education in Nigeria. In Proceedings of Frontiers in Education Conference. Institute of Electrical and Electronics Engineers. http://doi.org/10.1109/FIE.2016.7757541

Padmo, D., Idrus, O., \& Ardiasih, L. S. (2019). The utilization of mobile devices for improving access to online learning for distance education's students. Turkish Online Journal of Distance Education, 20(2), 147-161. https://eric.ed.gov/?id=EJ1213125

PC Magazine (2020). Definition of smartphone. https://www.pcmag.com/encyclopedia/term/smartphone

Pedro, L. F. M. G., Barbosa, C. M. M. d., \& Santos, C. M. d. (2018). A critical review of mobile learning integration in formal educational contexts. International Journal of Educational Technology in Higher Education, 15(1). https://doi.org/10.1186/s41239-018-0091-4 
Perrin, A. (2019). Digital gap between rural nonrural America persists. Pew Research Center. https://www.pewresearch.org/fact-tank/2019/05/31/digital-gap-between-rural-and-nonruralamerica-persists/

Pew Research Center. (2019, June 12). Mobile fact sheet. https://www.pewresearch.org/internet/fact-sheet/mobile/

Pimmer, C., Mateescu, M., \& Grohbiel, U. (2016). Mobile and ubiquitous learning in higher education settings. A systematic review of empirical studies. Computers in Human Behavior, 63, 1-18. https://doi.org/10.1016/j.chb.2016.05.057

Radosavljevic, S., Radosavljevic, V., \& Grgurovic, B. (2020). The potential of implementing augmented reality into vocational higher education through mobile learning. Interactive Learning Environments, 28(4), 404-418. https://doi.org/10.1080/10494820.2018.1528286

Regalado, M., \& Smale, M. A. (2019, December 6). "Technology is great, but it's really timeconsuming:" Understanding students' digital academic lives [Conference presentation]. CUNY IT Conference, New York, NY. https://academicworks.cuny.edu/ny_pubs/516/

Rideout, V. J. \& Katz, V. S. (2016). Opportunity for all? Technology and learning in lowerincome families. A report of the Families and Media Project. Joan Ganz Cooney Center at Sesame Workshop. https://www.joanganzcooneycenter.org/wpcontent/uploads/2016/01/jgcc_opportunityforall.pdf

Sandars, J., Correia, R., Dankbaar, M., de Jong, P., Goh, P., Hege, I., Masters, K., Oh, S.Y., Patel, R., Premkumar, K., Webb, A., \& Pusic, M. (2020). Twelve tips for rapidly migrating to online learning during the COVID-19 pandemic. MedEdPublish, 9. https://doi.org/10.15694/mep.2020.000082.1

Sadeque, S. (2020). COVID-19: The digital divide grows wider amid global lockdown. Inter Press Service. http://www.ipsnews.net/2020/05/covid-19-digital-divide-grows-wider-amidglobal-lockdown/

Sharma, G. (2017). Pros and cons of different sampling techniques. International Journal of Applied Research, 3(7), 749-752.

http://www.allresearchjournal.com/archives/2017/vol3issue7/PartK/3-7-69-542.pdf

Shisley, S. (2020, May 20). Emergency remote teaching compared to online learning. Learning Solutions Magazine. https://learningsolutionsmag.com/articles/emergency-remote-learningcompared-to-online-learning

So, S. (2016). Mobile instant messaging support for teaching and learning in higher education. The Internet and Higher Education, 31, 32-42. https://doi.org/10.1016/j.iheduc.2016.06.001 
Sobaih, A. E. E., Moustafa, M. A., Ghandforoush, P., \& Khan, M. (2016). To use or not to use? Social media in higher education in developing countries. Computers in Human Behavior, 58, 296-305. https://doi.org/10.1016/j.chb.2016.01.002

Suartama, I. K., Setyosari, P., Sulthoni, S., \& Ulfa, S. (2019). Development of an instructional design model for mobile blended learning in higher education. International Journal of Emerging Technologies in Learning, 14(16), 4-22. https://online-journals.org/index.php/ijet/article/view/10633

Sun, Z., Lin, C. H., Wu, M., Zhou, J., \& Luo, L. (2018). A tale of two communication tools: Discussion-forum and mobile instant-messaging apps in collaborative learning. British Journal of Educational Technology, 49(2), 248-261. https://doi.org/10.1111/bjet.12571

Taherdoost, H. (2016). Sampling methods in research methodology; how to choose a sampling technique for research. How to Choose a Sampling Technique for Research, 5. https://hal.archives-ouvertes.fr/hal-02546796

Tang, C. M., \& Bradshaw, A. (2016). The role of text messaging in team collaborative learning. In Proceedings of the 15th European Conference on E-Learning (pp. 672-679). Academic Conferences International. https://researchonline.jcu.edu.au/46307/

Troussas, C., Krouska, A., \& Sgouropoulou, C. (2020). Collaboration and fuzzy-modeled personalization for mobile game-based learning in higher education. Computers \& Education, 144, 103698. https://doi.org/10.1016/j.compedu.2019.103698

Vasudeva, S., Colthorpe, K., \& Ernst, H. (2017). Student-initiated mobile learning in higher education. In F. Loizides, G. Papadopoulos, \& N. Souleles (Eds.), Proceedings of the World Conference on Mobile and Contextual Learning. https://doi.org/10.1145/3136907.3136914

Vrana, R. (2015). The developments in mobile learning and its application in the higher education including libraries. In Proceedings of the International Convention on Information and Communication Technology, Electronics, and Microelectronics. Institute of Electrical and Electronics Engineers. https://doi.org/ 10.1109/MIPRO.2015.7160398

White, A.R. (2017, July 19-21). Exploring students' intentions to use mobile devices for educational purposes within a higher education context [Conference presentation]. International Conference on Creative Technology, Bangkok, Thailand.

https://www.researchgate.net/publication/318583663_Exploring_Students'_Intentions_to_Use_ Mobile Devices for Educational Purposes within a Higher Education Context 


\section{Appendix}

\section{Screening Questions}

\section{Mobile Device Use Survey}

- Are you currently enrolled in a fully online course, or have you taken a fully online course at a higher education institution in the past 6 months? (Y/N)

- Do you voluntarily use a mobile device (i.e., tablet or smartphone) for your coursework and/or courserelated activities? (In this case, voluntarily means that device use is not required, but you choose to use one for some or all course activities). (Y/N)

If individual answered "Yes" to both questions, they proceeded to the survey. If they answer "No" to either question, they received the following message:

- Thank you for your interest in participating in this study. However, in order to participate you must satisfy both screening criteria to proceed. Because you answered "No" to one or both questions, you did not pass the screening questions. Thank you for your time.

\section{Survey Questions}

Instructions: For the first set of questions, please select the box that corresponds to your answer.

What type of program are you currently enrolled in?

- Bachelor's

- Master's

- Doctoral

- Post-graduate certificate

- Other

What is your area of study?

- Business and Management

- Public Health and Health Sciences

- Information Technology

- Psychology and Counseling

- Social Work and Human Services

- Education

- Criminal Justice

- Public Policy and Administration

- Nursing

- Communication

- Other (Please describe)

What is your age?

- $18-29$

- 30-49

- $50-64$

- 65 and over

What is your ethnic/racial background?

- African American/Black

- Asian/Pacific Islander

- Hispanic/Latino

- Native American/American Indian

- White

- Not Listed (Please describe)

- Prefer not to respond 
What is your gender?

- Female

- Male

- Neither male or female

- If you chose "neither male or female" how do you identity yourself? (short answer)

- Prefer not to respond

Reflecting on your mobile device use for your online course(s) or course-related activities in the past 6 months, what type of mobile device do you use for your coursework and/or course-related activities? (check all that apply)

- Tablet

- Smartphone

- Other [please describe]

Instructions: The next five (5) questions are short-answer, typed responses that relate to your mobile device use in your online course(s). Prior to responding, reflect on your mobile device use for your online course(s) or courserelated activities over the past 6 months.

1. In a few words, describe the primary reasons why you chose to use a mobile device for your coursework and/or course-related activities. For example, one reason why you may use a mobile device might be for convenience.

2. Please provide an example or examples of how you used a mobile device for your coursework and/or course-related activities. For example, one way you may use a mobile device for your courses is for e-mail with your classmates.

3. Describe a challenge you encountered when using a mobile device for your coursework and/or courserelated activities. Be as specific as possible. If you never encountered a challenge, please indicate that you have never encountered a challenge.

4. With regards to the challenge described in question 3, how did you resolve (or attempt to resolve) the problem? If you were unable to resolve the problem, explain that as well.

5. With regards to the resolution (or attempted resolution) to the challenge you described in your response to question 3, in what other ways do you feel the issue could have been (or could be) resolved, if any?

Instructions: For the last set of questions, please select the box that corresponds to your answer. Prior to responding, reflect on your mobile device use for your online course(s) or course-related activities in the past 6 months.

Which of the following best describes how much you used a mobile device compared to a laptop or personal computer?

- I only use a mobile device and never use a laptop or personal computer for my online course(s) or courserelated activities.

- I use a mobile device more often than a laptop or personal computer for my online course(s) or courserelated activities.

- I use a mobile device less often than a laptop or personal computer for my online course(s) or courserelated activities.

How many times per week, on average, during your online course(s) do you use a mobile device for your coursework and/or course-related activities? In this instance, one "time" means when you pick up your device and use it for your course(s), even if you are using it for multiple activities.

- $\quad 0-2$ times per week

- 3-5 times per week

- 6-10 times per week

- More than 10 times per week 